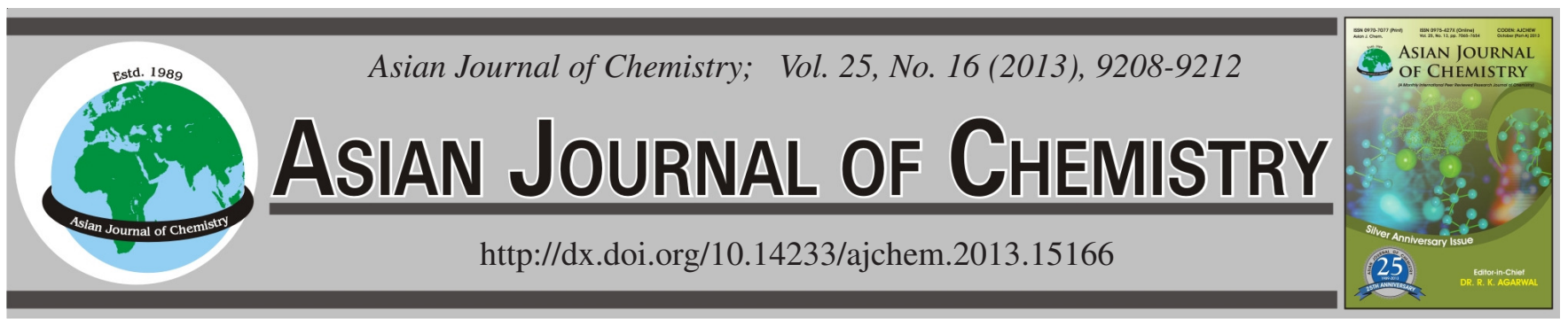

\title{
Effect of Humidity and Temperature on Dissipation of Chlorpyrifos and Diazinon in Andic Soils, Cauca, Colombia
}

\author{
E.H. PÉreZ ${ }^{1, *}$, M.I. PAEZ ${ }^{2}$ and A. FigueroA ${ }^{3}$
}

${ }^{1}$ Department of Chemistry, Universidad del Cauca, Calle 5 No 4-70 Popayan, Cauca, Colombia

${ }^{2}$ Department of Chemistry, Ciudad Universitaria Melendez, Universidad del Valle, AA 25360, Cali, Valle del Cauca, Colombia

${ }^{3}$ Department of Biology, Universidad del Cauca, Calle 5 No 4-70 Popayan, Cauca, Colombia

*Corresponding author: Tel: +57 2 8209800; Ext. 2611-2607; E-mail: ehperez@unicauca.edu.co

(Received: 17 January 2013;

Accepted: 20 September 2013)

AJC-14146

\begin{abstract}
The economic activity of a region depends on agriculture and livestock. This is characterized by having a potato growing (Solamumtuberosum Linneo) technique for high commercial production, which supplies the south-western Colombia. The andic soils have organic carbon content between 8.4 and $19.5 \%$, high humidity retention capacity, low temperatures. These soils are subjected to the application of high amounts of pesticides by farmers, being the most used chlorpyrifos and diazinon due to its control against potato weevil (Premnotrypesvorax, Coleoptera: Curculionidae) and foliage pests: flea (Epitrixspp, Coleoptera: Chrysomelidae) and Toston (Liriomyzaquadrata, Diptera: Agromyzidae), respectively. Incubating the soil with the pesticides and maintaining the containers at 278,288 and $298 \mathrm{~K}$ and humidities of $0,20,40,60$ and $100 \%$ with relation to the field humidity. $\mathrm{t}_{1 / 2}$ ranged from 86-122 days for chlorpyrifos and $42-53$ days for diazinon regardless of the amount of $\mathrm{CO}$ present in the soil. In general, it is concluded that the optimal conditions for the degradation of chlorpyrifos and diazinon in these soils are between $100-80 \%$ of humidity in field and a temperature below $283 \mathrm{~K}$, that is to say that the humidity in this case is leading to a faster degradation of pesticides.
\end{abstract}

Key Words: Dissipation, Degradation, Chlorpyrifos, Diazinon andic soil, Temperature, Humidity.

\section{INTRODUCTION}

The constant use of pesticides in agriculture, has led to learn more about the processes of adsorption and degradation of these products in the soil solution and in the colloids thereof, that given the great adsorption influence on the performance of pesticides in their soil mobility and in the waste they can leave. Since not all soils have the same behaviour related to pesticides, it is necessary to carry out specific degradation studies of these compounds in andic soils intended to the potatoes growing because of their specific weather conditions of heights, temperature and humidity.

The retention of organic compounds by mineral and organic soil constituents depends on the humidity. Chiou and Shoup ${ }^{1}$ and Gondar et al. ${ }^{2}$ found that in dry soils, adsorption of pesticides is mainly the result of its interaction with the mineral components, whereas in humid soils is the organic matter which has this dominance. This is due to the strong dipole interaction between the mineral fraction of soil and water molecules, which excludes the organic compounds, especially the low solubility ones in water of this fraction of soil. Wauchope et al. ${ }^{3}$ revises and abridge the theory, measurement, uses and limitations of the adsorption parameters of pesticides in soil. Agudelo et al. ${ }^{4}$ evaluated the removal of the pesticide chlorpyrifos and dissolved organic matter in wastewater of a rural area in a small scale registering removals of 96.2 and $93.2 \%$, respectively. Since water is a polar compound, is strongly adsorbed on the soil organic matter adsorption sites leaving few free active sites for the pesticide adsorption. It is considered that higher humidity will accelerate the degradation processes. Walker and Zimdahl ${ }^{5}$, proposed an empirical relationship for explaining the dependence of humidity with relation to the half -life of a pesticide, using the expression $\mathrm{t}_{1 / 2 \mathrm{M}}=\mathrm{A} \cdot \mathrm{M}^{-\mathrm{B}}$ where $\mathrm{t}_{1 / 2 \mathrm{M}}$ is $\mathrm{t}_{1 / 2}$ at a $\mathrm{M}$ humidity content, $\mathrm{A}$ and $\mathrm{B}$ are constants.

Veeh et al. ${ }^{6}$ concluded that the optimal conditions for the pesticides degradation is between $30-40{ }^{\circ} \mathrm{C}$ and $50-90 \%$ humidity at field capacity. Zhang et al. ${ }^{7}$ reported that chlorpyrifos and diazinon in aqueous solution can be rapidly and effectively degraded by ultrasonic radiation, $\mathrm{pH}$ and temperature. Fenlon et al. ${ }^{8}$ and Briceño et al. ${ }^{9}$ concluded that the biodegradation of diazinon and chlopyrifos depends on the soil type, $\mathrm{pH}$ and the presence of bacteria that degrade it and take into account for quantification effects the used extraction method. 
Adsorption processes are exothermic, while desorption is endothermic, so that a temperature increase will lead to a decreased adsorption and an increased desorption. Moreover, a temperature increase accelerates the reactions, i.e., to say, increase the degradation processes of any pesticide and this dependency is described by the Arrhenius equation: $\mathrm{K}=\mathrm{Ae}^{-\mathrm{E} / \mathrm{RT}}$ where $\mathrm{K}$ is the degradation pesticide constant, $\mathrm{E}_{\mathrm{a}}$ is the activation energy ( $\mathrm{kcal} / \mathrm{mol}), \mathrm{R}$ is the universal gas constant (1.987 cal $/ \mathrm{mol}), \mathrm{T}$ is the absolute temperature (Kelvin), $\mathrm{A}$ is a constant.

Calculation of the half-life pesticide and GUS number (Groundwater, Ubiquity Store): $t_{1 / 2}$ is defined as the time it takes to degrade the half of the pesticide initial concentration. To calculate, this case $t_{1 / 2}$ the pesticide concentration values measured over time were adjusted, to a linear form of a first order kinetics, which is represented by the equation $\log \mathrm{C}=\log \mathrm{C}_{\mathrm{o}}-\mathrm{K}_{\mathrm{t}}$, where $\mathrm{C}$ is the pesticide measured over time $t, C_{o}$ the pesticide concentration at time zero and $\mathrm{K}$ is the dissipation constant; the half-life in this case, is obtained by the equation $\mathrm{t}_{1 / 2}=\mathrm{Ln} 2 / \mathrm{K}$.

GUS is an empirical number derived from the relationship between the pesticide persistence value $\left(t_{1 / 2}\right)$ and its adsorption coefficient due to $\mathrm{CO}\left(\mathrm{K}_{\mathrm{oc}}\right)$ in the soil. It is calculated GUS = $\log _{10} t_{1 / 2^{*}}\left(4-\log _{10} K_{o c}\right)$ and is used to predict the potential movement of the pesticide to contaminate groundwater. A value of $4.0<<0.1<<$ GUS considered a high to an extremely slow movement of a pesticide in the soil profile.

\section{EXPERIMENTAL}

Location and characteristics of the study zone: The zone where the samples were taken is located in the department of Cauca, Totoró municipality and belongs to the Gabriel Lopez small town. It is located on the central Colombian cordillera that corresponds to the Andean region, Calvache wetland, between the geographical coordinates 76.17"51 W, 2.3"34 N. Geomorphologically, the zone soils belong to the called intermountain hills. The relief is undulating to extremely undulating; it presents deep dissections, with short and medium slopes, rectilinear of 7-12-25-50\%. Some sectors have gently undulating relief and others, become heavily rolling. The weather is very cold (moorland) which belongs to the living area of very wet mountain forest (bmh-M), affected by frequent frosts and strong winds. Temperatures range from 273 to $293 \mathrm{~K}$ and precipitation ranges between 1200 and $1800 \mathrm{~mm}$ annually. The parent material is volcanic ash covering different geological materials, mainly sand and volcanic tuffs.

Sampling: Disturbed soil samples were air dried and subsequently sieved to $2 \mathrm{~mm}$ and stored at room temperature. The physical and chemical properties and classifications according to $\mathrm{USDA}^{10}$ were determined in soil testing laboratories of the International Research Centre for Tropical Agriculture (CIAT) and chemical laboratories of the University of Valle, using the methodologies reported in IGAC ${ }^{11}$.

Strategy to determine the temperature and effect of humidity: There were taken $200 \mathrm{~g}$ of sieved soil $(2 \mathrm{~mm})$ everyday, they were incubated with chlorpyrifos and diazinon pesticides with a final theoretical concentration of $10 \mathrm{mg} / \mathrm{Kg}$ of soil. Once treated soil was homogenized and left for $24 \mathrm{~h}$ to reach equilibrium.
Each plot was divided into 10 portions of $20 \mathrm{~g}$ to be humudify with different amounts of $0.01 \mathrm{M} \mathrm{CaCl}_{2}$ to achieve the appropriate humidity (Table-1) and was incubated at different temperatures.

TABLE-1

STRATEGY TO STUDY THE OF HUMIDITY AND TEMPERATURE EFFECT ON THE DISSIPATION OF PESTICIDES CHLORPYRIFOS AND DIAZINON

\begin{tabular}{cccc}
\hline Treatment & $\begin{array}{c}\text { Humidity in relation to the } \\
\text { field capacity }(\%)\end{array}$ & $\begin{array}{c}\text { Humidity } \\
(\%)\end{array}$ & $\begin{array}{c}\text { Temp. } \\
(\mathrm{K})\end{array}$ \\
\hline $100-25$ & 100 & 82.3 & 298 \\
$100-15$ & 100 & 82.3 & 288 \\
$100-5$ & 100 & 82.3 & 278 \\
$60-15$ & 60 & 49.4 & 288 \\
$40-15$ & 40 & 32.9 & 288 \\
$20-15$ & 20 & 16.5 & 288 \\
$0-15$ & 0 & 0 & 288 \\
\hline
\end{tabular}

The soil humidification was homogeneously made and evaporation losses within containers were replaced every week by weight difference. Seven different treatments were carried with three andic soils with different organic matter percentages, resulting 21 containers.

The initial pesticides concentration in soil samples was determined and the homogeneity in every one of the containers after incubation was verified. each of the containers samples were measured on days $0,3,10,20,40,60,100,130$ after initiating treatment and for duplicate, taking representatively $1 \mathrm{~g}$ of soil container in a test tube provided with a hermetic lid which was frozen at $243 \mathrm{~K}$ until the extraction moment and analysis that did not exceed $24 \mathrm{~h}$.

\section{Detection method}

Removal of pesticides from soil: $1 \mathrm{~g}$ of soil was taken from each container, $5 \mathrm{~mL}$ of acetone was added. It was subjected to ultrasound for $0.5 \mathrm{~h}$, centrifuged for 10 minutes at $8000 \mathrm{rpm}$, the supernatant was passed through filter 0.22 $\mathrm{mm}$ and $0.2 \mu \mathrm{L}$ were injected to the GC-ECD.

Equilibration time: It was determined in the laboratory that the equilibration time for pesticides study in percentage ranges of organic carbon in these soils, is reached after $11 \mathrm{~h}$ of application based on $\mathrm{SSSA}^{12}$.

Identification of main soil properties for soil classification: The zone soils are intended to potato monoculture and presents less than $25 \% \mathrm{CO}$ and in its fine fraction. The aluminium percentage plus the half iron percentage (extraction with ammonium oxalate) is higher than $2 \%$. The apparent density measured at 0.3 bar retention of water is less than $0.90 \mathrm{~g} / \mathrm{cm}^{3}$ and phosphorus retention is higher than $90 \%$ (Table-2). These properties are met until $60 \mathrm{~cm}$ depth of soil. This allowed to find out that these soil conform with andic properties and are therefore andic.

All profiles showed a superficial, thick and dark horizon with the properties required by the melanicor umbric, epipedon dystrophic, with high rate of aluminium exchange and high humidity retention at 15 bar.

\section{RESULTS AND DISCUSSION}

The graphs in Fig. 1 belong to the soils 1, 2 and 3 which were treated with pesticides chlorpyrifos and diazinon provided 
TABLE-2

CHARACTERISTICS OF CLASSIFICATION AND SOME STUDIED ANDIC SOIL PROPERTIES $(0-30 \mathrm{~cm})$

\begin{tabular}{|c|c|c|c|c|c|c|c|c|c|c|c|}
\hline Soil & $\begin{array}{l}\text { Munsell colour* in } \\
\text { humudity }\end{array}$ & $\begin{array}{l}\mathrm{CO} \\
(\%)\end{array}$ & $\begin{array}{l}\mathrm{Ar} \\
(\%)\end{array}$ & $\begin{array}{l}\text { Aparentdensity } \\
\left(\mathrm{g} / \mathrm{cm}^{3}\right)\end{array}$ & $\begin{array}{c}\text { Porosity } \\
(\%)\end{array}$ & $\begin{array}{c}\text { Humidity }(0.3 \\
\text { Bar })(\%)\end{array}$ & $\mathrm{pH}$ & $\begin{array}{l}\text { Phosphate } \\
\text { retention (\%) }\end{array}$ & $\begin{array}{l}\mathrm{Al}+1 / 2 \\
\mathrm{Fe}(\%)\end{array}$ & $\begin{array}{c}\text { CIC } \\
(\mathrm{meq} / 100 \mathrm{~g})\end{array}$ & $\begin{array}{l}\mathrm{CHS} \\
(\mathrm{m} / \mathrm{d})\end{array}$ \\
\hline 1 & 10YR4.5/4(darkbrown) & 8,4 & 20,2 & 0.47 & 82 & 67.4 & 4,7 & 92 & 2.6 & 39.8 & 10.2 \\
\hline 2 & 7.5YR25/1(black) & 14,1 & 22,6 & 0.53 & 77 & 60.5 & 4,7 & 96 & 3.1 & 29.8 & 2.6 \\
\hline 3 & 7.5YR25/1 (black) & 19,5 & 15,4 & 0.40 & 82 & 68.3 & 4,9 & 97 & 3.2 & 42.1 & 2.6 \\
\hline
\end{tabular}

"Munsell soil colour charts (2000).

\section{Chlorpyrifos}

Soil 1

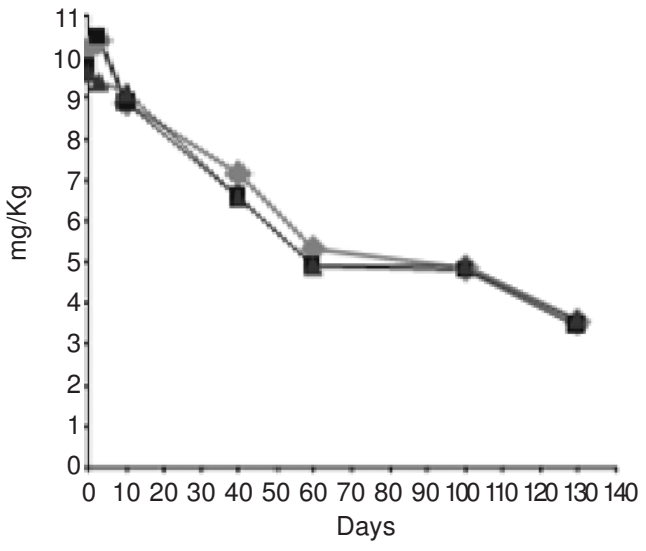

Soil 2

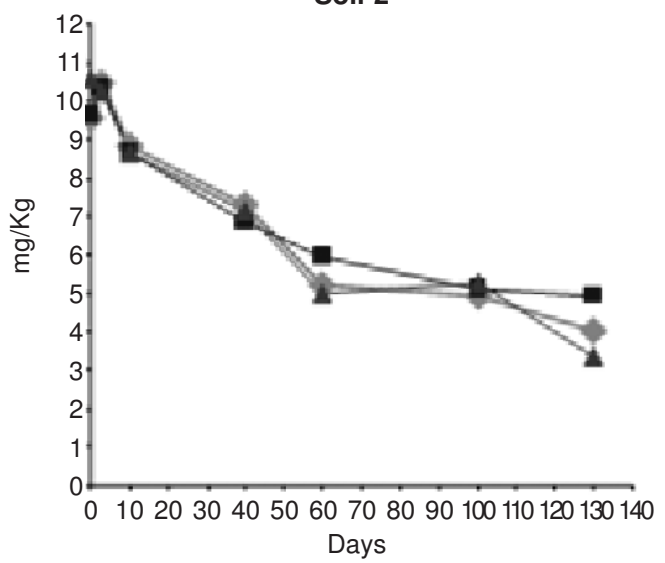

Soil 3

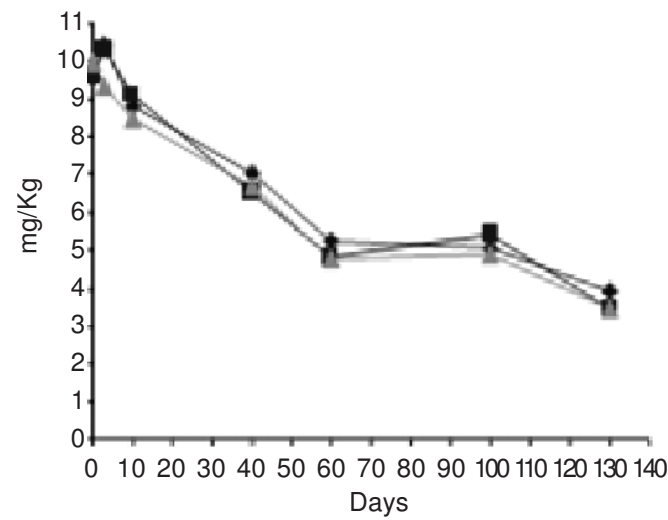

Diazinon

Soil 1

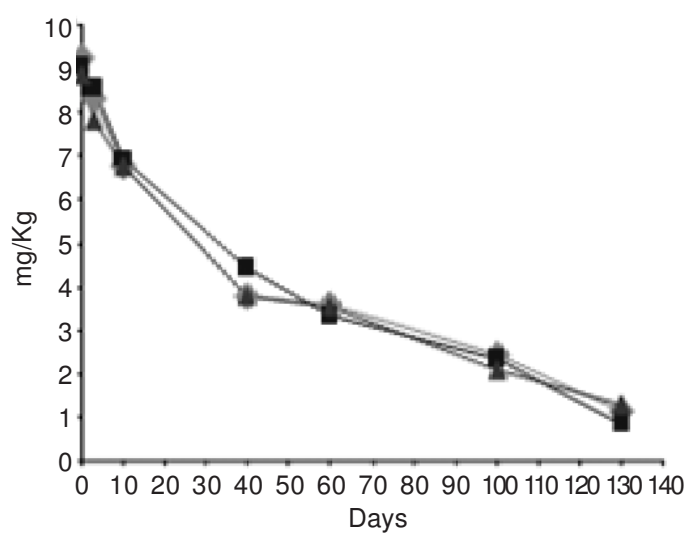

Soil 2

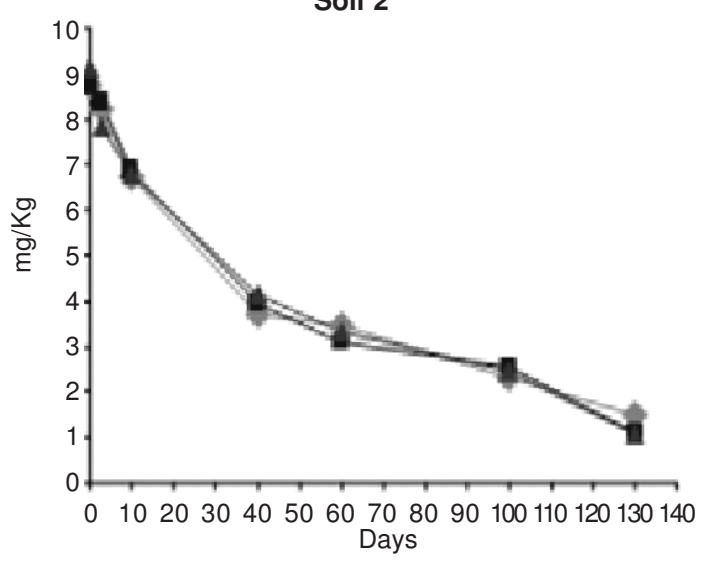

Soil 3

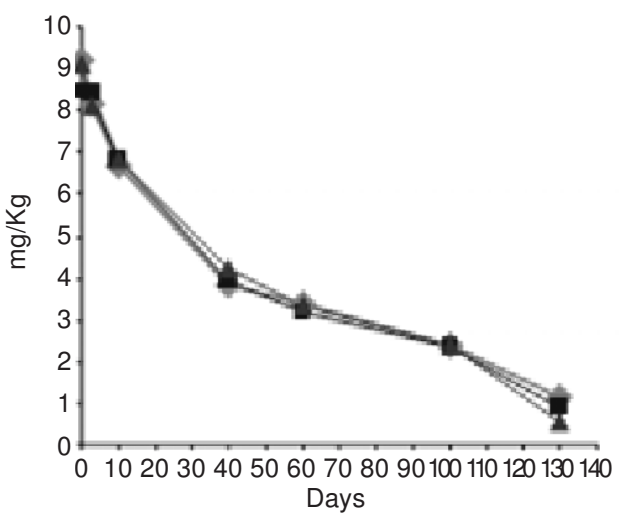

Temperature $\left({ }^{\circ} \mathrm{C}\right): \square+298 \mathrm{~K}=288 \mathrm{~K}=278 \mathrm{~K}$

Fig. 1. Dissipation curves of the temperature effect of pesticides in soil 
$100 \%$ field humidity measured at 0.3 bar and represent these pesticides degradation by the temperature effect over time. Similarity is apparent degradation in the range of temperature of $278-298 \mathrm{~K}$ for both pesticides can be verified. The $t_{1 / 2}$ ranging from 86 to 122 days for chlorpyrifos and 42 to 53 days to diazinon (Table-3).

\section{Chlorpyrifos}

Soil 1

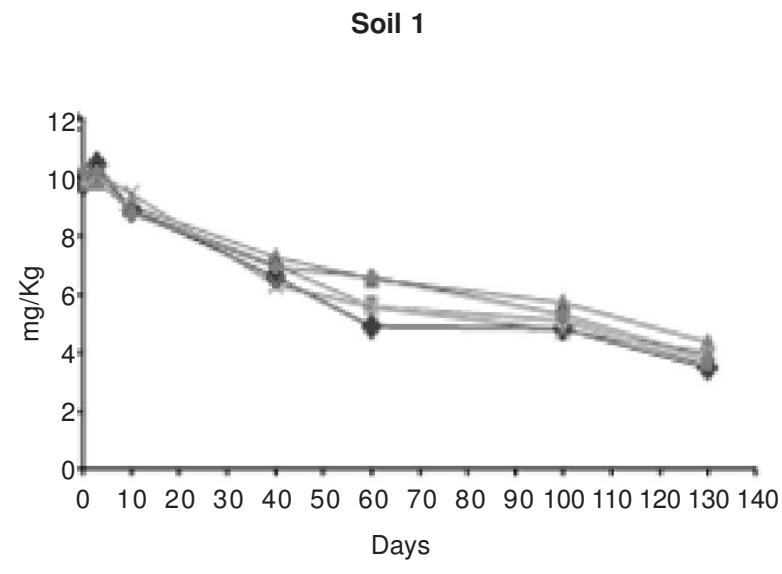

Soil 2

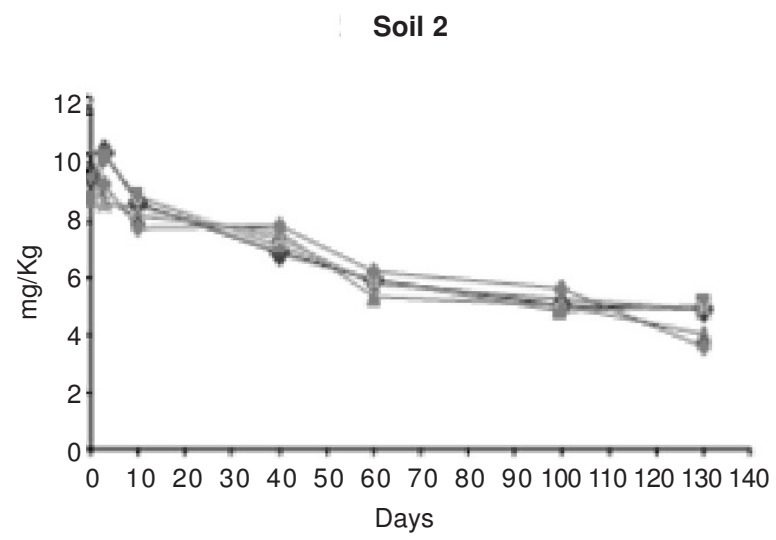

Soil 3

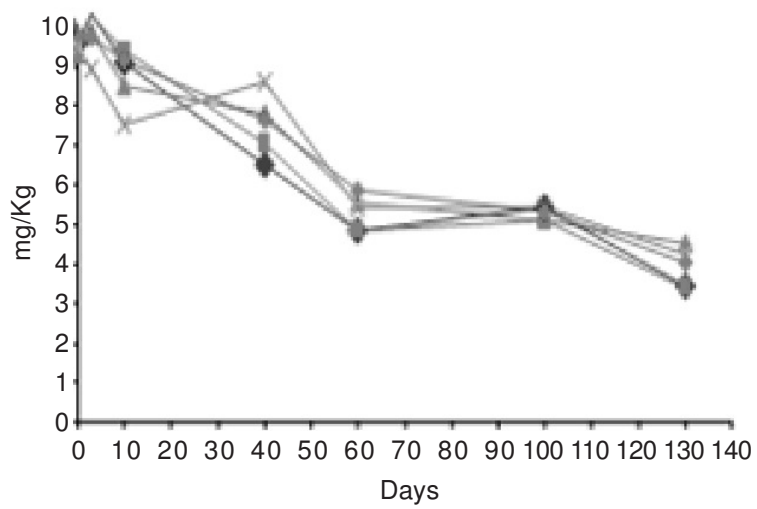

The graphs in Fig. 2 show the studied pesticides degradation by the effect of soil humidity content with respect to humidity at 0.3 bar at a constant temperature of $288 \mathrm{~K}$. It is also observed a great similarity in the degradation for a more steepening descending curve with 100 and $80 \%$ of the field humidity. In the equation of the line, the slope is the degradation
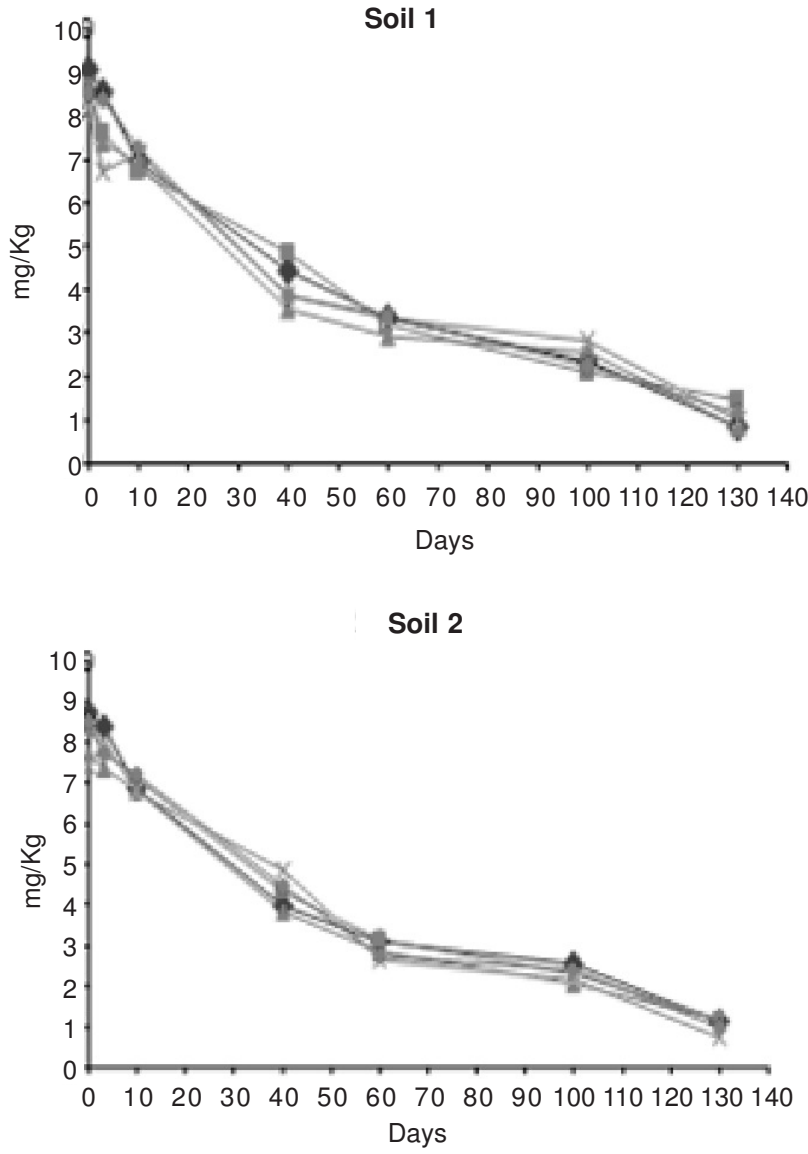

Soil 3

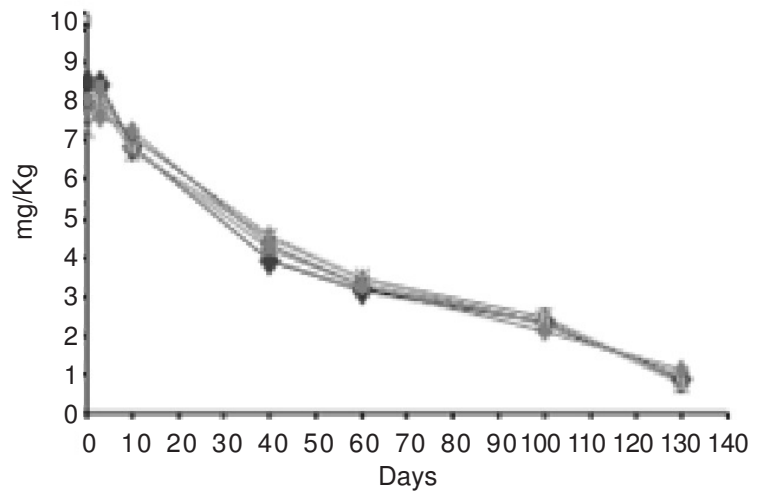

Humidity (\% in relation to field humidity):

$\longrightarrow+100-60 \div-40 \div-20$

Fig. 2. Degradation of pesticides chlorpyrifos and diazinon to different humidity at constant temperature (288 K) 
TABLE-3

HALF-LIFE OF THE PESTICIDE CHLORPYRIFOS AND DIAZINON AT DIFFERENT TEMPERATURE CONDITIONS

\begin{tabular}{ccc}
\hline & \multicolumn{2}{c}{ Soil } \\
\cline { 2 - 3 } Temperature $(\mathrm{K})$ & Chlorpyrifos & Diazinon \\
\cline { 2 - 3 } & \multicolumn{2}{c}{$\mathrm{t}_{1 / 2}$ (days) } \\
\hline \multicolumn{3}{c}{1} \\
298 & 86 & 48 \\
278 & 85 & 42 \\
& 93 & 50 \\
\hline 298 & 2 & 53 \\
288 & 29 & 48 \\
278 & 122 & 47 \\
\hline 298 & 86 & 47 \\
288 & 3 & 44 \\
278 & 98 & 38 \\
\hline
\end{tabular}

constant in each temperature condition at constant humidity, assuming studied pesticides are degraded under these conditions using standard first order kinetics. The $\mathrm{R}^{2}$ higher than 0.94 for the pesticide chlorpyrifos, diazinon varies from 0.79 to 0.91 . In all given cases, the shape and curvature of the isotherms are classified as type $\mathrm{C}$, characterized by a constant contribution of the affinity between the soil and pesticides. Although for the pesticide chlorpyrifos case a slight tendency for type $S$ isotherm is observed, indicating that adsorption among the pesticide, water and previously adsorbed molecules, is relevant in this process.

Table-4 presents a summary for pesticide and soil of the constants $\mathrm{E}_{\mathrm{a}}, \mathrm{A}$ and $\mathrm{B}$ values and GUS number. Observing the highest degradation of chlorpyrifos and diazinon in the soil 1, low activation energy and low values for the constants A and B.

\begin{tabular}{ccccc}
\multicolumn{5}{c}{ TABLE-4 } \\
SUMMARY OF THE HUMIDITY EFFECT \\
QUANTIFYING CONSTANTS AND TEMPERATURE \\
ON THE DEGRADATION AND GUS NUMBER FOR \\
\hline \multicolumn{4}{c}{ PESTICIDES: (a) CHLORPYRIFOS, (b) DIAZINON } \\
\hline Soil & $\mathrm{E}_{\mathrm{a}}(\mathrm{Kcal} / \mathrm{mol})$ & $\mathrm{A}$ & $\mathrm{B}$ & $\mathrm{GUS}$ \\
\hline 1 & 0,65 & 16,68 & $-0,037$ & 0,93 \\
2 & 8,92 & 24,94 & $-0,088$ & 0,04 \\
3 & 1,82 & 32,97 & $-0,200$ & 0 \\
\hline
\end{tabular}

There are marked differences in the degradation of diazinon, which is faster than the chlorpyrifos' in all soils. Likewise with the GUS number where it can be predicted a soil profile movement more efficient of diazinon than chlorpyrifos in these types of soils.

In general and observing Figs. 2 and 3, it is concluded that the humidity effect does not take priority in the diazinon degradation by the fact that three different soil at different humidity percentage during the period which lasted the experiment show approximately the same degradation rate. However there is evidence that there is degradation due to the temperature where the half- life time is higher at lower temperatures. This is ratified by the low values of $\mathrm{B}$ and high values of $E_{a}$ (Table-4) that its degradation is independent of humidity but dependent of temperature. For chlorpyrifos, there is dependence of humidity in the degradation with high values of $\mathrm{B}$ and it shows moderate temperature dependence, where the half life time is lower at low temperatures.

\section{Conclusion}

In the studied andic soils it was found a faster degradation due to temperature effect and the pesticide diazinon humidity (42 to 53 days) than chlorpyrifos (86-122 days) It is also shown with the number used to predict the GUS pesticide potential movement where it where a movement in the soil profile more effective in diazinon than in chlorpyrifos can be predicted. Applying the empirical relationship proposed by Walter and Zimdahl $^{5}$ it was found out that in these soils A ranged from 16.68 to 32.97 for chlorpyrifos and B between -0037 and -0200 whereas for diazinon A was determined between 14.0 and 17.7 and $\mathrm{B}$ between -0.05 and -0.02 demonstrating an effective participation of the water amount present in the soils in the pesticides degradation processes.

\section{ACKNOWLEDGEMENTS}

GEA (Environmental Studies Group) University of Cauca (Colombia), University of Valle (Colombia) and COLCIENCIAS for partial financial support in carrying out this project, CIAgua (International Water Centre) for their contributions to the publication.

\section{REFERENCES}

1. C.T. Chiou and T.D. Shoup, Environ. Sci. Technol., 16, 4 (1985).

2. D. Gondar, R. López, J. Antelo, S. Fiol and F. Arce, J. Hazard. Mater., 235-236, 218 (2012).

3. R.D. Wauchope and R.A Leonard, J. Environ. Qual., 9, 665 (1980).

4. R.M. Agudelo, G. Peñuela, N.J. Aguirre, J. Morató and M.L. Jaramillo, Ecol. Eng., 36, 1401 (2010).

5. A. Walker and R.L. Zimdahl, Weed Res., 21, 255 (1981)

6. R.H. Veeh, W.P. Inskeep and A.K. Camper, Environ. Qual., 25, 5 (1996).

7. Y. Zhang, Y. Hou, F. Chen, Z. Xiao, J. Zhang and X. Hu, Chemosphere, 82, 1109 (2011).

8. K.A. Fenlon, K. Andreou, K.C. Jones and K.T. Semple, Environ. Pollut., 159, 776 (2011).

9. G. Briceño, M.S. Fuentes, G. Palma, M.A. Jorquera, M.J. Amoroso and M.C. Diez, Int. Biodeter. Biodegr., 73, 1 (2012).

10. United States Department of Agriculture(USDA), Keys to Soil Taxonomy, Washington, DC, USA, edn. 8, Ch. 2 and 6 (1998).

11. Instituto Geográfico Agustín Codazzi (IGAC), Métodos analíticos del laboratorio de suelos, Bogotá, DC. Colombia, edn. 6 (2006).

12. H. Cheng, Soil Science Society of America (SSSA): Pesticide in the Soil Environment: Processes Impacts and Modeling, SSSA Book Series, Wisconsin, pp. 431-432 (1990). 